\title{
A trans influence study in propyl (aquo)cobaloxime by imidazoles and amino acids
}

\author{
J V MADHURI and S SATYANARAYANA* \\ Department of Chemistry, Osmania University, Hyderabad 500 007, India \\ e-mail: ssnsirasani@yahoo.com
}

MS received 11 October 2004; accepted 23 February 2005

\begin{abstract}
Substitution reactions of propyl cobaloxime with imidazole, substituted imidazoles, histidine, histamine, glycine and ethyl glycine ester are carried out as a function of $\mathrm{pH}$. Trends in the formation constants are explained based on the steric hindrance, extent of $\pi$-bonding and $\sigma$-donor capacity of the incoming ligand. Molecular mechanics is used to theoretically determine the bond length and bond strain values by MM2 parametrization and these are correlated with the experimental data.
\end{abstract}

Keywords. Spectrophotometry; equilibrium constants; trans influence; molecular mechanics; Co-C bond.

\section{Introduction}

Adenosyl cobalamin (Adocbl) is an essential cofactor for at least 17 different enzymatic systems. ${ }^{1-4}$ A key to the reactivity of Adocbl is in the cleavage of the biologically rare $\mathrm{Co}-\mathrm{C}$ bond. Exactly how Adocbldependent enzymes accomplish rate acceleration [ $10^{12}$-fold acceleration] is still not well understood ${ }^{5,6}$ In recent years, there were several attempts to replicate them in experimental model systems with varying success. ${ }^{7-10}$ Among the vitamin $B_{12}$ models, organocobaloximes are noteworthy because of their ability to accommodate a wide variety of metal-bound alkyl groups containing a large number of different types of substituents. ${ }^{11}$ There has been continual interest to examine the steric cis and trans effects in these cobaloximes to study the factors influencing the $\mathrm{Co}-\mathrm{C}$ bond cleavage. The strength of the $\mathrm{Co}-\mathrm{C}$ $\sigma$-bond depends on several factors. These are the equatorial ligands which influence the redox potential of the central cobalt ion; the character of the ligand in the trans position to the $\mathrm{R}$ group; the character of the substituents on the aliphatic residue $\mathrm{R}$; steric hindrance which stems from the equatorial ligand structure and from the substituents on R.

The present paper describes the equilibrium and molecular mechanistic studies performed for propyl

\footnotetext{
*For correspondence
}

(aquo)cobaloxime with a series of ligands to unravel the differences in $\mathrm{Co}-\mathrm{C}$ and $\mathrm{Co}-\mathrm{N}$ bond lengths.

\section{Materials and methods}

Imidazole (Imd), 1-methyl imidazole (1-Meimd), 2methyl imidazole (2-Meimd), 1,2 dimethyl imidazole (1,2-Dimeimd), 2-ethyl imidazole (2-Etimd) (Acros) and histidine (Histd), histamine (Hisamn), glycine (Gly), ethyl glycine ester (Etglyest) and alkylating agents (Sigma-Aldrich) were used as purchased. Potassium dihydrogen phosphate, potassiumphosphate, tris(hydroxymethyl)-aminomethane (Tris) were obtained from Acros. Propyl (aquo) cobaloximes were prepared according to earlier reported procedure. ${ }^{12}$ All manipulations were performed under minimal illuminations due to photolability of organocobalt bond. $^{13}$

$\mathrm{pH}$ values were determined with a Digisun digital $\mathrm{pH}$ meter equipped with a combination glass electrode. The electrode was standardized at two $\mathrm{pH}$ values (4.0 and 9.2). UV-visible spectra were recorded on a Hitachi U-3410 spectrophotometer. Throughout the study, the concentration of propyl (aquo)cobaloxime was maintained as $0.001 \mathrm{M}$ and absorption was fixed at $436 \mathrm{~nm}$. Axial ligation kinetics was monitored by an Elico single beam spectrophotometer SL 171 model, the sample compartment of which was thermostatted at $25 \pm 0 \cdot 1^{\circ} \mathrm{C}$. 


\section{Results and discussion}

\subsection{Trans influence studies}

A trans influence study includes investigations of all possible steric and electronic changes detectable in trans ligands. Cobaloximes have been the preferred systems for such studies in octahedral systems. Usually, the trans ligand is varied, and changes in the cis equatorial dioxime ligand are monitored. For this, apparent equilibrium constants for the axial ligation of alkyl(aquo)cobaloximes were determined spectrophotometrically. Solutions containing propyl cobaloxime, an appropriate buffer $(0.2 \mathrm{M})$ to maintain $\mathrm{pH}, \mathrm{KCl}$ to maintain ionic strength $(1.0 \mathrm{M})$ and varying concentrations of ligand are taken in $3 \mathrm{ml}$ cuvettes and allowed to equilibrate in the thermostatted cell compartment holder at $25 \pm 0 \cdot 1^{\circ} \mathrm{C}$ for $15 \mathrm{~min}$ prior to the addition of propyl cobaloxime:

$$
K_{\text {app }}=\frac{\left[\mathrm{CH}_{3} \mathrm{CH}_{2} \mathrm{CH}_{2} \mathrm{Co}(\mathrm{DH})_{2} \mathrm{~L}\right]}{\left[\mathrm{CH}_{3} \mathrm{CH}_{2} \mathrm{CH}_{2} \mathrm{Co}(\mathrm{DH})_{2} \mathrm{OH}_{2}\right][\mathrm{L}]_{\text {free }}} \text {. }
$$

For a given $\mathrm{pH}, K_{\text {app }}$ is calculated from the experimental data as below,

$$
\Delta A=\Delta A_{\max }[\mathrm{L}]_{f} /\left[\left(1 / K_{\mathrm{app}}+[\mathrm{L}]_{f}\right],\right.
$$

where $\Delta A$ is the difference in absorbance between solutions containing cobaloxime with added ligand (L) and solutions containing only cobaloxime at the same concentration, $\Delta A_{\max }$ is the maximum absorbance change thus obtained at high $[\mathrm{L}]_{T}$, and $[\mathrm{L}]_{f}$ is the unbound ligand concentration. The data are analysed by a least-squares fit to a rearranged form of (2) to give,

$$
\begin{aligned}
& {[\mathrm{L}]_{f}=[\mathrm{L}]_{T}-\left(C_{T} \Delta A / \Delta A_{\max }\right),} \\
& \Delta A=\Delta A_{\max }-1 / K_{\text {app }} \Delta A /[\mathrm{L}]_{f},
\end{aligned}
$$

$[\mathrm{L}]_{f}$ is calculated from (3) using the measured value of $\Delta A$ and $\Delta A_{\max },[\mathrm{L}]_{T}$ is the total concentration of added ligand and $C_{T}$ is the total concentration of cobaloxime.

From the UV-Vis spectra (figure 1) of $\mathrm{C}_{3} \mathrm{H}_{7} \mathrm{Co}$ $(\mathrm{DH})_{2} \mathrm{OH}_{2}$ recorded for varying concentrations of histidine, it is evident that as the concentration of histidine increases, absorbance decreases. Values of $K_{\text {app }}$ are evaluated from the least-squares fit of (4) and the slope is $-1 / K_{\text {app }}$. The $\mathrm{pH}$ independent binding constant $K_{\text {eq }}$ is calculated from the relation $K_{\text {eq }}=$
$K_{\text {app }} / \alpha_{L}$, where $\alpha_{L}=K a /\left(K a+\left[\mathrm{H}^{+}\right]\right), K a$ is the dissociation constant of the ligand. Table 1 summarizes the values of equilibrium constants and $K_{\text {app }}$ for the reaction of all the ligands with propyl (aquo) cobaloxime. Logarithmic plots of $\log K_{\text {app }}$ vs $\mathrm{pH}$ are shown in figure 2, from which it is obvious that as the $\mathrm{pH}$ increases, the $K_{\text {app }}$ value increases and after a certain value of $\mathrm{pH}$, they become independent of $\mathrm{pH}$. Affinities of the ligands follow the order, 1Meimd $>$ Imd $>$ Histd $>$ Hisamn $>$ Gly $>$ Glyest $>2$ Meimd > 1,2Dimeimd > 2-Etimd.

The order of these ligands may be explained by considering the HSAB principle, basicity of ligands and their ability of $\pi$-bonding and $\sigma$-donation. The series of imidazoles and substituted imidazoles follow the order, 1-Meimd $>$ Imd $>2$-Meimd $>$ 1,2dimeimd $>2$-etimd. For 1-meimd and Imd the formation constants are high for higher $\mathrm{pKa}$ values i.e. they follow the basicity order. From 2-meimd to 2-etimd, steric hindrance at $\mathrm{C}_{2}$ position of the imidazole plays a role and they do not follow the basicity order. $\mathrm{pH}$ dependence plots of $\log K_{\text {app }}$ for imidazole reveal that, initially as the $\mathrm{pH}$ increases, $\log K_{\text {app }}$ increases indicating that imd free base is the only ligating species. With further increase in $\mathrm{pH}$, $K_{\text {app }}$ reaches maximum value as the availability of free imidazole is maximm at higher $\mathrm{pH}$ values and for further rise in $\mathrm{pH}, K_{\text {app }}$ is $\mathrm{pH}$ independent.

If we consider the amino acid series, they fall in the order, Histd $>$ Hisamn $>$ Gly $>$ Etglyest. In the case of histamine and histidine, there is no increase in $K_{\text {app }}$ at $\mathrm{pH}$ above the $\mathrm{pKa}$ of the ligand indicating that the binding is through the endocyclic nitrogen. If it binds through $\mathrm{NH}_{2}$ group at higher $\mathrm{pH}$, there should be an increase in $K_{\text {app }}$ even at higher $\mathrm{pH}$.

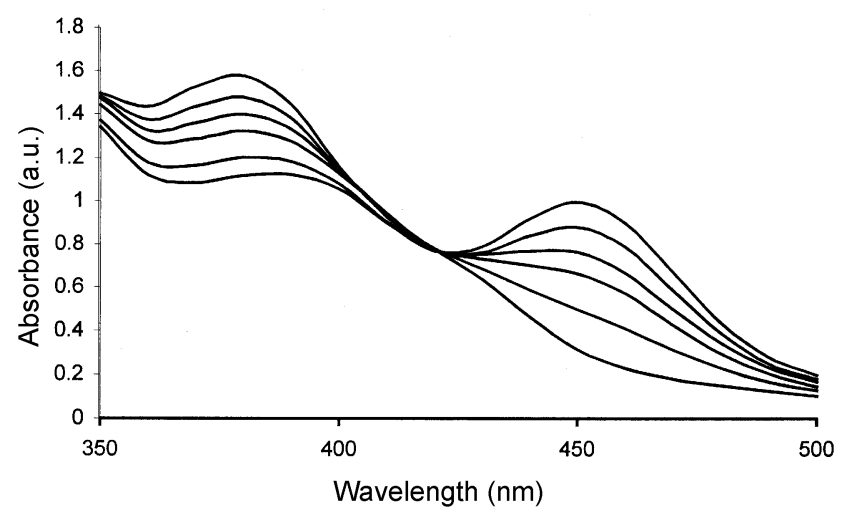

Figure 1. Binding of $\left[\mathrm{C}_{3} \mathrm{H}_{7} \mathrm{Co}(\mathrm{DH})_{2} \mathrm{OH}_{2}\right]$ with varying concentrations of histidine at $\mathrm{pH} 7.5$ and $25^{\circ} \mathrm{C}$. 
Table 1. Formation constants (log $K_{\text {app }}$ values) for the $\left[\mathrm{C}_{3} \mathrm{H}_{7} \mathrm{Co}(\mathrm{DH})_{2} \mathrm{~L}\right]$ complexes.

\begin{tabular}{|c|c|c|c|c|c|c|c|c|}
\hline $\mathrm{pH}$ & Hisamn & Histd & Gly & Etglyest & 1-Meimd & Imd & 2-Meimd & 2-Etimd \\
\hline $4 \cdot 5$ & $2 \cdot 28$ & $2 \cdot 5$ & & & & & & \\
\hline $5 \cdot 0$ & $2 \cdot 4$ & $2 \cdot 7$ & & & 1.47 & $1 \cdot 9$ & & \\
\hline $5 \cdot 5$ & $2 \cdot 56$ & $2 \cdot 89$ & & & $2 \cdot 05$ & 1.95 & & \\
\hline $6 \cdot 0$ & 2.79 & $3 \cdot 1$ & & & $2 \cdot 58$ & $2 \cdot 0$ & & \\
\hline $6 \cdot 5$ & $3 \cdot 0$ & $3 \cdot 2$ & & & $3 \cdot 01$ & $2 \cdot 46$ & & \\
\hline $7 \cdot 0$ & $3 \cdot 17$ & $3 \cdot 25$ & & & $3 \cdot 2$ & $2 \cdot 82$ & $1 \cdot 3$ & $0 \cdot 382$ \\
\hline $7 \cdot 5$ & $3 \cdot 3$ & $3 \cdot 3$ & & $2 \cdot 0$ & $3 \cdot 3$ & 3.06 & 1.4 & $0 \cdot 818$ \\
\hline $8 \cdot 0$ & $3 \cdot 4$ & $3 \cdot 31$ & $1 \cdot 51$ & $2 \cdot 18$ & $3 \cdot 35$ & $3 \cdot 1$ & $1 \cdot 5$ & $1 \cdot 163$ \\
\hline $8 \cdot 5$ & $3 \cdot 44$ & $3 \cdot 33$ & 1.99 & $2 \cdot 22$ & $3 \cdot 4$ & $3 \cdot 12$ & $1 \cdot 62$ & $1 \cdot 358$ \\
\hline $9 \cdot 0$ & $3 \cdot 445$ & $3 \cdot 35$ & $2 \cdot 44$ & $2 \cdot 3$ & & & 1.66 & 1.45 \\
\hline $9 \cdot 5$ & & & 2.78 & $2 \cdot 35$ & & & 1.69 & $1 \cdot 5$ \\
\hline $10 \cdot 0$ & & & $2 \cdot 9$ & $2 \cdot 35$ & & & $1 \cdot 72$ & $1 \cdot 52$ \\
\hline $10 \cdot 5$ & & & 2.995 & $2 \cdot 35$ & & & & \\
\hline $11 \cdot 0$ & & & $3 \cdot 0$ & $2 \cdot 37$ & & & & \\
\hline $11 \cdot 5$ & & & & & & & & \\
\hline$K_{\mathrm{eq}}$ & 1765 & 2190 & 1846 & 180 & 2316 & 1761 & 51 & 32 \\
\hline
\end{tabular}

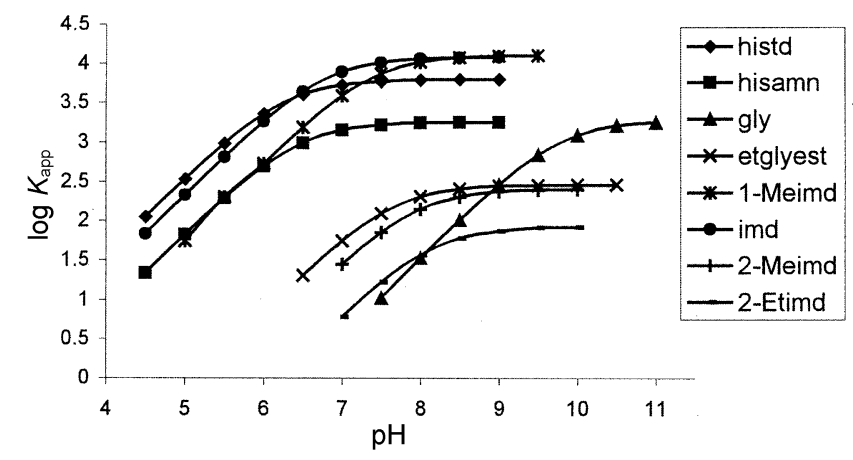

Figure 3. Dependence of $\log K_{\text {app }}$ on the $\mathrm{pH}$ for the axial ligation of $\mathrm{C}_{3} \mathrm{H}_{7} \mathrm{Co}(\mathrm{DH})_{2} \mathrm{OH}_{2}$ by different ligands at $25^{\circ} \mathrm{C}$.

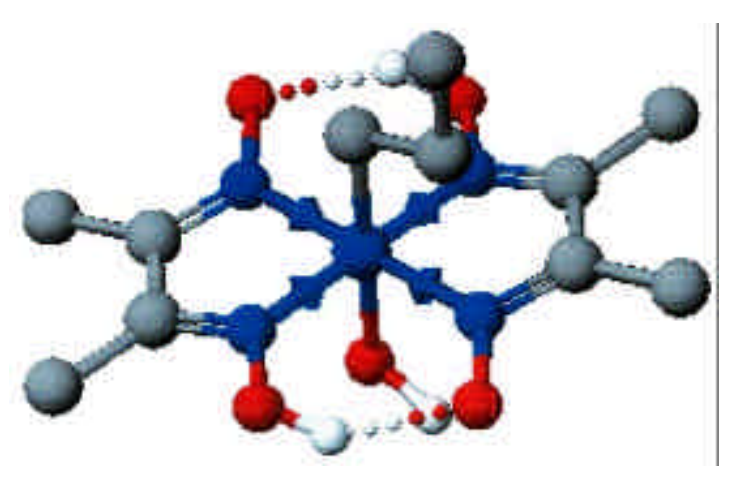

Figure 3. A ball and stick representation of the minimum energy structure of $\left[\mathrm{C}_{3} \mathrm{H}_{7} \mathrm{Co}(\mathrm{DH})_{2} \mathrm{H}_{2} \mathrm{O}\right]$ (centre dark blue: cobalt, light blue: nitrogen; red: oxygen, grey: carbon, white: hydrogen).

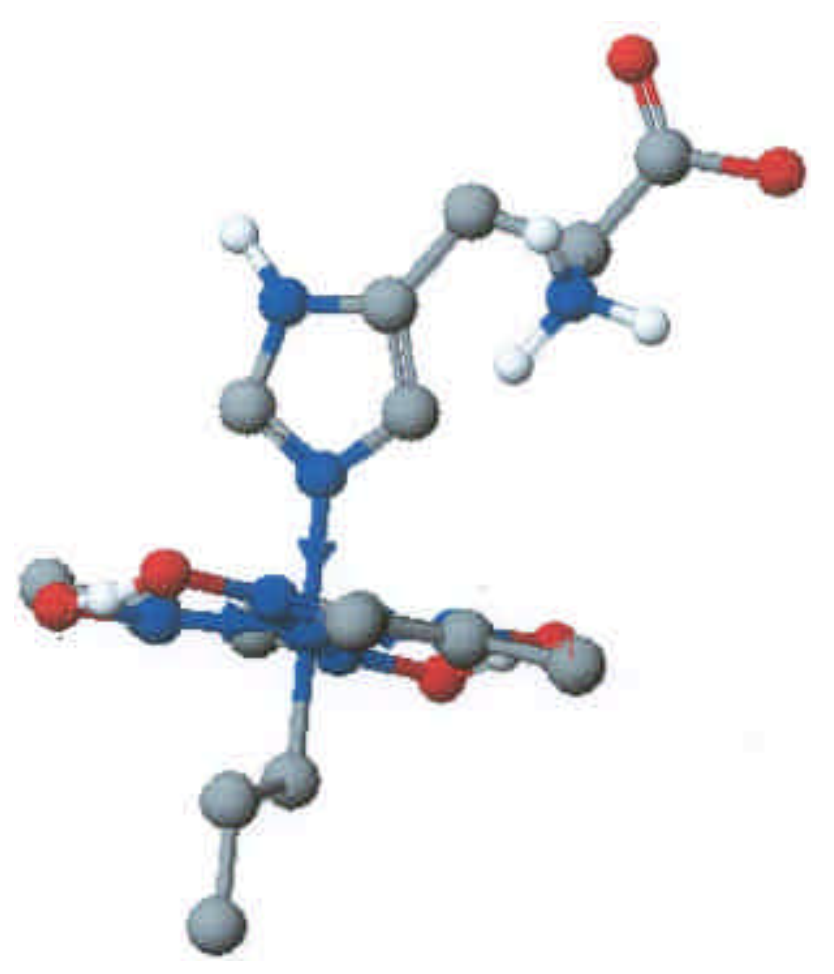

Figure 4. A ball and stick representation of the minimum energy structure of $\left[\mathrm{C}_{3} \mathrm{H}_{7} \mathrm{Co}(\mathrm{DH})_{2}\right.$ Histd $]$ obtained by MM calculations. Colour codes as in figure 3.

With histidine, coordination is through the nitrogen of the imidazole ring, though there is a possibility of $\mathrm{COO}^{-}$and $\mathrm{NH}_{2}$ coordination, the $\mathrm{NH}_{2}$ is mostly protonated below $\mathrm{pH} 8.0$, hence not available for bind 
Table 2. Bond lengths and bond strain values (in parentheses) obtained from molecular mechanics studies with propyl(aquo) cobaloxime.

\begin{tabular}{|c|c|c|c|c|c|c|c|c|c|}
\hline & Aquo & Histd & Hisamn & Gly & Etglyest & Imd & 1-Meimd & 2-Meimd & 2-Etimd \\
\hline $\mathrm{Co}-\mathrm{N}(1)$ & $\begin{array}{c}1 \cdot 940 \\
(0 \cdot 198)\end{array}$ & $\begin{array}{c}1 \cdot 942 \\
(0 \cdot 219)\end{array}$ & $\begin{array}{c}1 \cdot 942 \\
(0 \cdot 206)\end{array}$ & $\begin{array}{c}1.943 \\
(0.227)\end{array}$ & $\begin{array}{c}1 \cdot 942 \\
(0 \cdot 201)\end{array}$ & $\begin{array}{c}1 \cdot 942 \\
(0 \cdot 217)\end{array}$ & $\begin{array}{c}1 \cdot 941 \\
(0 \cdot 210)\end{array}$ & $\begin{array}{c}1.944 \\
(0.251)\end{array}$ & $\begin{array}{c}1 \cdot 945 \\
(0 \cdot 254)\end{array}$ \\
\hline $\mathrm{Co}-\mathrm{N}(2)$ & $\begin{array}{c}1 \cdot 942 \\
(0 \cdot 201)\end{array}$ & $\begin{array}{c}1 \cdot 943 \\
(0 \cdot 232)\end{array}$ & $\begin{array}{c}1 \cdot 942 \\
(0 \cdot 217)\end{array}$ & $\begin{array}{c}1.944 \\
(0.237)\end{array}$ & $\begin{array}{c}1 \cdot 942 \\
(0 \cdot 227)\end{array}$ & $\begin{array}{c}1 \cdot 943 \\
(0 \cdot 220)\end{array}$ & $\begin{array}{c}1 \cdot 943 \\
(0 \cdot 229)\end{array}$ & $\begin{array}{c}1 \cdot 944 \\
(0 \cdot 244)\end{array}$ & $\begin{array}{c}1 \cdot 944 \\
(0 \cdot 248)\end{array}$ \\
\hline $\mathrm{Co}-\mathrm{N}(3)$ & $\begin{array}{c}1.934 \\
(0 \cdot 100)\end{array}$ & $\begin{array}{c}1.937 \\
(0.133)\end{array}$ & $\begin{array}{c}1.936 \\
(0 \cdot 122)\end{array}$ & $\begin{array}{c}1.937 \\
(0 \cdot 136)\end{array}$ & $\begin{array}{c}1.936 \\
(0 \cdot 137)\end{array}$ & $\begin{array}{c}1.936 \\
(0 \cdot 121)\end{array}$ & $\begin{array}{c}1.936 \\
(0.127)\end{array}$ & $\begin{array}{c}1.937 \\
(0 \cdot 140)\end{array}$ & $\begin{array}{c}1.938 \\
(0 \cdot 147)\end{array}$ \\
\hline $\mathrm{Co}-\mathrm{N}(4)$ & $\begin{array}{c}1 \cdot 934 \\
(0 \cdot 105)\end{array}$ & $\begin{array}{c}1.935 \\
(0 \cdot 127)\end{array}$ & $\begin{array}{c}1.935 \\
(0.115)\end{array}$ & $\begin{array}{c}1.936 \\
(0 \cdot 122)\end{array}$ & $\begin{array}{c}1.935 \\
(0 \cdot 118)\end{array}$ & $\begin{array}{c}1.936 \\
(0 \cdot 122)\end{array}$ & $\begin{array}{c}1.936 \\
(0 \cdot 117)\end{array}$ & $\begin{array}{c}1.936 \\
(0.132)\end{array}$ & $\begin{array}{c}1.938 \\
(0 \cdot 147)\end{array}$ \\
\hline $\mathrm{Co}-\mathrm{C}$ & $\begin{array}{c}1.954 \\
(0 \cdot 183)\end{array}$ & $\begin{array}{c}1.956 \\
(0.205)\end{array}$ & $\begin{array}{c}1.956 \\
(0 \cdot 206)\end{array}$ & $\begin{array}{c}1.956 \\
(0 \cdot 209)\end{array}$ & $\begin{array}{c}1.955 \\
(0 \cdot 203)\end{array}$ & $\begin{array}{c}1.955 \\
(0 \cdot 198)\end{array}$ & $\begin{array}{c}1.955 \\
(0 \cdot 196)\end{array}$ & $\begin{array}{c}1.956 \\
(0 \cdot 206)\end{array}$ & $\begin{array}{c}1.956 \\
(0 \cdot 210)\end{array}$ \\
\hline $\mathrm{Co}-\mathrm{N}$ & - & $\begin{array}{c}1 \cdot 935 \\
(0 \cdot 100)\end{array}$ & $\begin{array}{c}1.934 \\
(0.099)\end{array}$ & $\begin{array}{c}1.929 \\
(0 \cdot 118)\end{array}$ & $\begin{array}{c}1 \cdot 929 \\
(0 \cdot 112)\end{array}$ & $\begin{array}{c}1 \cdot 934 \\
(0 \cdot 103)\end{array}$ & $\begin{array}{c}1.934 \\
(0 \cdot 102)\end{array}$ & $\begin{array}{c}1.949 \\
(0.332)\end{array}$ & $\begin{array}{c}1 \cdot 951 \\
(0 \cdot 370)\end{array}$ \\
\hline $\mathrm{N}(1)-\mathrm{C}(1)$ & $\begin{array}{c}1 \cdot 262 \\
(0 \cdot 003)\end{array}$ & $\begin{array}{c}1 \cdot 262 \\
(0.004)\end{array}$ & $\begin{array}{c}1.262 \\
(0 \cdot 004)\end{array}$ & $\begin{array}{c}1.262 \\
(0 \cdot 003)\end{array}$ & $\begin{array}{c}1 \cdot 262 \\
(0 \cdot 002)\end{array}$ & $\begin{array}{c}1 \cdot 262 \\
(0 \cdot 003)\end{array}$ & $\begin{array}{c}1 \cdot 262 \\
(0 \cdot 004)\end{array}$ & $\begin{array}{c}1.262 \\
(0.004)\end{array}$ & $\begin{array}{c}1 \cdot 262 \\
(0 \cdot 003)\end{array}$ \\
\hline $\mathrm{N}(2)-\mathrm{C}(2)$ & $\begin{array}{c}1 \cdot 262 \\
(0 \cdot 003)\end{array}$ & $\begin{array}{c}1 \cdot 261 \\
(0 \cdot 002)\end{array}$ & $\begin{array}{c}1 \cdot 262 \\
(0 \cdot 004)\end{array}$ & $\begin{array}{c}1 \cdot 262 \\
(0 \cdot 003)\end{array}$ & $\begin{array}{c}1 \cdot 262 \\
(0 \cdot 003)\end{array}$ & $\begin{array}{c}1 \cdot 262 \\
(0 \cdot 004)\end{array}$ & $\begin{array}{c}1 \cdot 262 \\
(0 \cdot 003)\end{array}$ & $\begin{array}{c}1 \cdot 262 \\
(0 \cdot 005)\end{array}$ & $\begin{array}{c}1 \cdot 262 \\
(0 \cdot 004)\end{array}$ \\
\hline $\mathrm{N}(3)-\mathrm{C}(3)$ & $\begin{array}{c}1 \cdot 261 \\
(0 \cdot 001)\end{array}$ & $\begin{array}{c}1 \cdot 261 \\
(0 \cdot 003)\end{array}$ & $\begin{array}{c}1 \cdot 261 \\
(0 \cdot 002)\end{array}$ & $\begin{array}{c}1 \cdot 261 \\
(0 \cdot 001)\end{array}$ & $\begin{array}{c}1 \cdot 261 \\
(0 \cdot 002)\end{array}$ & $\begin{array}{c}1 \cdot 261 \\
(0 \cdot 001)\end{array}$ & $\begin{array}{c}1 \cdot 261 \\
(0 \cdot 001)\end{array}$ & $\begin{array}{c}1 \cdot 261 \\
(0 \cdot 001)\end{array}$ & $\begin{array}{c}1 \cdot 262 \\
(0 \cdot 003)\end{array}$ \\
\hline $\mathrm{N}(4)-\mathrm{C}(4)$ & $\begin{array}{c}1 \cdot 261 \\
(0 \cdot 002)\end{array}$ & $\begin{array}{c}1 \cdot 261 \\
(0.002)\end{array}$ & $\begin{array}{c}1.261 \\
(0 \cdot 002)\end{array}$ & $\begin{array}{c}1 \cdot 261 \\
(0 \cdot 002)\end{array}$ & $\begin{array}{c}1 \cdot 262 \\
(0.002)\end{array}$ & $\begin{array}{c}1.262 \\
(0 \cdot 002)\end{array}$ & $\begin{array}{c}1 \cdot 262 \\
(0 \cdot 002)\end{array}$ & $\begin{array}{c}1.261 \\
(0 \cdot 001)\end{array}$ & $\begin{array}{l}1 \cdot 26 \\
(0 \cdot 001)\end{array}$ \\
\hline
\end{tabular}

$\mathrm{N}(1), \mathrm{N}(2), \mathrm{N}(3), \mathrm{N}(4)$ are the nitrogen atoms that bond with the cobalt mimicking the corrin ring system

$\mathrm{C}(1), \mathrm{C}(2), \mathrm{C}(3), \mathrm{C}(4)$ are the carbon atoms attached to the nitrogens present in the entity mimicking the corrin ring system

$\mathrm{C}$ (carbon atom) in the propyl cobaloxime and $\mathrm{N}$ (nitrogen atom) in the ligand that bond with the cobalt atom

ing. Though histamine is slightly more basic than histidine, histidine forms a more stable complex than histamine because histidine is a better $\pi$-acceptor than histamine.

$K_{\mathrm{Gly}}>K_{\text {Etglyest }}$ may be explained based on the basicity of the ligands, as both are $\sigma$-donors. Glycine is more basic than glycine ester and hence forms more stable complexes than glycine ester. If we compare the $\mathrm{pH}$ dependent binding plots of glycine and glycine ester in both cases $K_{\text {app }}$ increases with increase in $\mathrm{pH}$ and after a certain $\mathrm{pH}$ value they become $\mathrm{pH}$-independent.

"Soft" (or class b) character has been assigned to alkyl cobaloximes. ${ }^{14-16}$ This is evident from the greater ligand affinity of imidazole ${ }^{17-21}$ histidine or histamine compared to "hard" glycine or ethyl glycine ester. Further, softness may be directly related to the ability of a cobalt complex to stabilize a carbon-cobalt bond as seen in the cobaloximes.

The order of stability of the complexes may be attributed to the ability of imidazoles or histidine or histamine to accept electrons into higher-energy unfilled $\pi^{*}$ anti-bonding orbitals through $d \pi-p \pi$ back- bonding. But glycine and ethyl glycine ester cannot accept electrons in either fashion. A reverse order for the dependence of $\mathrm{RCo}(\mathrm{DH})_{2} \mathrm{~L}$ stability on ligand basicity among the two series of ligands, aromatic (histamine, histidine, imidazole and substituted imidazoles) and aliphatic (glycine and ethyl glycine ester) is not unexpected owing to the following reasons.

(i) An increase in basicity is associated with increased ability for $\sigma$-donation;

(ii) An increase in basicity is associated with the decreased ability of the aromatic ligands to function as $\pi$-acceptors. Hence, though histamine is more basic than histidine it forms slightly less stable complexes than histidine.

\subsection{Molecular mechanistic studies}

Molecular mechanics is a tool of increasing importance for structural investigations of coordination and organometallic chemistry. ${ }^{22-25}$ In molecular mechan- 
ics, mathematical equations are used to simulate all the components that contribute to the strain energy of a molecule, which is then minimized to find a low energy conformation. $E_{s}, E_{t}, E_{b}$ and $E_{\mathrm{vdw}}$ were calculated using standard MM protocols.

In the present work, we have performed geometry optimization using MM2 parameterization provided in the Bio Med CACache 5.02 software. Figures 3 and 4 are the ball and stick representations of propyl (aquo) and propyl(histd)cobalximes respectively generated in the work space of the software. Bondlength and bond-strain values are then evaluated and compared. Table 2 illustrates the values that are obtained performing MM2 parameterization and are in confirmation with the binding data.

\section{Conclusions}

In this study we have observed that the formation constants follow the trend, 1-Meimd $>$ Imd $>$ Histd $>$ Hisamn $>$ Gly $>$ Glyest $>2$-Meimd $>1$,2Dimeimd $>$ 2-Etimd. This is explained based on the $\partial$-bonding and basicity of the ligands ( $\mathrm{p} K_{a}$ values). Though 2meimd to 2-etimd are basic than Imd, they form less stable complexes due to steric hindrance. Co(III) is soft and hence binds more strongly to histidine and histamine as compared to glycine and ethyl glycine ester. From the molecular mechanics studies, the effect of incoming ligand on the $\mathrm{Co}-\mathrm{C}$ bond is revealed.

\section{References}

1. Sirovatka J M and Finke R G 1999 Inorg. Chem. 38 1697

2. Sirovatka J M and Finke R G 2001 Inorg. Chem. 40 1082
3. Brasch N E and Haupt R J 2000 Inorg. Chem. 39 5469

4. Doll K M and Finke R G 2004 Inorg. Chem. 43 2611

5. Helder H M, Warden C, Monye M, Shongwe M S and Brown K L 1998 Inorg. Chem. 372578

6. Licht S S, Lawrence C C and Stubbe J 1999 Biochemistry 381234

7. Hisaeda Y, Ogawa A, Ohno T and Murakami Y 1998 Inorg. Chim. Acta 273299

8. Sudarshan Reddy D, Rajeshwar Rao A and Satyanarayana S 2002 Indian J. Chem. A41 2475

9. Madhuri J V, Malathi V and Satyanarayana S $2004 J$. Chem. Sci. 116143

10. Hamza M S A, Zou X, Brown K L and van Eldik R 2002 J. Chem. Soc., Dalton Trans. 3832

11. Toscano P J and Marzilli L G 1984 Prog. Inorg. Chem. 31105

12. Brown K L 1986 Organomet. Synth. 3186

13. Brown K L and Kallen R G 1972 J. Am. Chem. Soc. 941894

14. Crumbliss A L and Wilmarth W K $1970 \mathrm{~J}$. Am. Chem. Soc. 922593

15. Hagve D N and Halpern J 1967 Inorg. Chem. 62059

16. Siang H G T and Wilmarth W K 1968 Inorg. Chem. 7 2535

17. Sridhar V and Satyanarayana S 2000 Proc. Indian Acad. Sci. (Chem. Sci.) 112579

18. Sridhar V and Satyanarayana S 2001 Indian J. Chem. A40 165

19. Bhoopal M, RaviKumar Reddy N and Satyanarayana S 2003 Proc. Indian Acad. Sci. (Chem. Sci.) 11583

20. Sudarshan Reddy D and Satyanarayana S 2003 Proc. Indian Acad. Sci. (Chem. Sci.) 115175

21. Sudarshan Reddy D, Rajeshwar Rao A and Satyanarayana S 2002 Indian J. Chem. A41 2475

22. Natalie F 1999 J. Chem. Technol. Biotechnol. 74 852

23. Bersukker I B, Leong M K, Boggs J E and Pearl Man R S 1997 Bull. Soc. Chil. Quim. 42405

24. Cini R, Gianluca G, Franco L, Claudio R and Marzilli L G 1990 J. BioMol. Struct. Dyn. 7859

25. Allinger N L 1977 J. Am. Chem. Soc. 998127 